\title{
From Cyborg Feminism to Drone Feminism: Remembering Women's Anti-nuclear Activisms
}

Anna Feigenbaum

\begin{abstract}
:
In 2003, Iris Marion Young argued that by the early 1990s the creative civil disobedience of Greenham Common and the broader women's anti-nuclear movement had been 'all but forgotten' (Young, 2003: 1). The dynamic array of symbols, myths, strategies and tactics for direct action against militarized technologies that emerged from women's anti-nuclear protest camps in the 1980s became largely eclipsed by cyber-feminisms focused on digital and online technologies. Yet recently, as robots and algorithms are put forward as the vanguards of new drone execution regimes, some are wondering if now is the time for another Greenham Common. In this paper I return to cyborg feminism and anti-nuclear activisms of the 1980s to explore what a drone feminism might look like today. I examine how anti-nuclear protesters infused affect and techné, creating innovative images of, and tactics for, material resistance. I argue that Greenham women's cyborg feminisms arose from their material entanglements with the technologies and environments of the military base. In their efforts to challenge, undermine and reveal the national and imperial myths upon which warfare is based, protesters re-imagined technological possibilities based upon a global accountability for 'earthly survival.'
\end{abstract}

Keywords: militarism, cyborg feminism, drones, Donna Haraway, feminist activism

Bio: Anna Feigenbaum is a Senior Lecturer at the Journalism School at Bournemouth University. She has held fellow positions at the Rutgers Center for Historical Analysis and the London School of Economics and Political Science. Her writing is published in a range of outlets, including Sociological Review, Feminist Media Studies, The Guardian and Al Jazeera America. She is an associate and fellow of the Higher Education Academy and is a trained facilitator and community educator, running group development workshops for academics, NGOs and local initiatives. She can be found on twitter at @drfigtree.

In 2003, Iris Marion Young argued that by the early 1990s the creative civil disobedience of Greenham Common and the broader women's anti-nuclear movement had been 'all but forgotten' (Young, 2003: 1). As organized violence and protectionist 
discourses of state security took on new forms in the post-9/11 War on Terror, Western feminist analyses of male domination and militarism largely faded from center stage. Young was not alone in her nostalgia for the vibrant direct actions and debates that gave life to women's activisms around nuclear proliferation. Back in the 1980s, Donna Haraway also garnered inspiration for her Cyborg Manifesto from the creative direct actions of women's ant-nuclear activisms.

Originally published by the Socialist Review in 1985 under the title "Manifesto for cyborgs: science, technology, and socialist feminism in the 1980s," Haraway's now famous text is, in no small part, an examination of women's anti-nuclear activism during the early 1980s. The text explicitly acknowledged anti-nuclear activists at Greenham Common as cyborg feminists par excellence.

[Nuclear cruise missiles] are floating signifiers moving in pickup trucks across Europe, blocked more effectively by the witch-weavings of the displaced and so unnatural Greenham women, who read cyborg webs of power so very well, than by the militant labor of older masculinist politics (Haraway, 1991: 154).

Further tying her manifesto to women's anti-militarism, in the opening footnote for the reprinted 'Cyborg Manifesto' that appears in Simians, Cyborgs, and Women, Haraway acknowledges colleagues and graduate students engaged in the debates and discussions that arose from feminist conferences and workshops on military technologies in 1983 and 1984. She again notes in her introduction to the Haraway Reader, 'Many of the entities that command my attention were birthed through the reproductive apparatuses of war' (Haraway, 2004: 3). 
Such reproductive apparatuses of war, in a Post 9/11 world, fueled Young's concerns about the lack of critical feminist activisms in a time when 'war' was increasingly becoming boundless and constant, while civil liberties, and the right to dissent, were eroded at home (Young 2003). While Young's lament perhaps overstated her case, ignoring important postcolonial and anti-imperialist work at the time, now, over a decade after Young's critique, Feminist International Relations and Politics scholars are once again calling for more critical Western feminist voices to challenge the counter-terrorism doctrine-and in particular, the proliferation of drone executions (Blanchard 2011). Reminiscences of feminism anti-nuclear activist pasts come to the surface. Writing for the Guardian on 7 June 2013, Zoe Williams questioned whether the UK could see a new Greenham protest camp emerge at drone-operational site RAF Waddington. Likewise, political commentator @oxfordgirl asked her thousands of followers, 'The new Greenham Common? Welsh airfield at the centre of Britain's drone revolution.'

In this paper I turn back to Western women's anti-nuclear activisms in the 1980 s to contribute to emergent feminist scholarship around drones and their infrastructures. I put forward the notion of a drone feminism, situating our contemporary moment in the historical activist legacy of resistance to nuclear proliferation. I ask, what are the trajectories of these anti-militarist feminisms? How has Western feminism addressed—and failed to address - the oppressive and colonial forces of its military technologies? Where have the witch-weaving feminist cyborgs of the women's anti-nuclear movement gone? Or rather, in what new forms might they already exist? What adapted tactics and activist techniques might they take on? Before I turn to explore these questions by remembering 
some of the cyborg feminism of the 1980s anti-nuclear movement, I offer a brief introduction to the proliferation of drone technologies and their implications.

\section{The Rise of the Drones}

In the time that has passed since Young's call for more creative civil disobedience against patriarchal militarisms, we have seen the proliferation of drone technologies in the United States and beyond (Young, 2003). Usually used as a lay term to refer to Unmanned Aerial Vehicles (UAVs), the term 'drone' itself is contested, said both to oversimplify the complex, networked technologies drones comprise, as well as to obscure the role of humans (and other nonhumans) in drone infrastructure (Shaw and Akhter 2012). In the United States the use of unmanned aircraft steadily increased between the mid-1980s and turn of the $21^{\text {st }}$ century, deployed in the Balkans and during Operation Desert Storm. Between 2000 and 2009 the United States arsenal of unmanned aircraft skyrocketed from 50 to 6800 (Bourke, 2014). By 2009 the US was buying more unmanned than manned aircraft (Shaw and Aktar, 2012). The US has used these drones extensively in Iraq and Afghanistan, as well as in Libya, Somalia, Pakistan and Yemen (Asaro, 2013).

While by far the largest purveyor, the US is not alone in the proliferation of military drones. In its recent publication, the Center for New American Security reported that over 90 countries and non-state actors operate drones, including 10 with armed drones, and at least 20 more are developing weaponised drones (Sayler, 2015). Weaponised drones range from small aircraft able to carry lightweight explosives and operate with real-time transmission, to 'stealth' missile-wielding aircraft that can stay airborne for up to 24 hours, operate in controlled airspace and engage in 'all-weather terrain mapping and target 
tracking via low-probability-of-intercept radar' (Sayler, 2015: 27). Such powerful drones are being researched, developed and tested in Russia, Israel, Chine, India, France, Italy, Sweden, Spain, Greece, Switzerland and the UK (Sayler, 2015). In a time of recession and austerity, despite defense industry budget cuts, 'the drones market is booming and a considerable amount of money is spent on research \& development' (marketsandmarkets.com).

While these drones are relatively new to active military duty, research and development into unmanned aircraft is over 100 years old. Evidencing Haraway's argument that by the late $19^{\text {th }}$ century, militarized science had already breached the boundary between machine and animal, proto-drones from the early 1900s included pigeons affixed to cameras to capture aerial photographs (Haraway 2001). This was followed by B. F. Skinner's attempts to build a pigeon-guided missile in World War II (Stromburg, 2011). This breaching of birds and machines characterizes much of the development of drones. As Wilkinson explains:

Drones are frequently assigned bird names that correspond with their size and capabilities: there is the hawk, the raven, the lark, the hummingbird and so on. In researching and designing drones, scientists maintain the animal connection by studying birds' physiology and flight patterns in order to determine more effective ways for drones to navigate tight and narrow spaces (Wilkinson, 2013: 4).

Insects, as the word drone itself suggests, are also analyzed for drone research and development. The US Navy's recent LOCUST (Low-Cost UAV Swarming Technology) drones are fired out of a cannon. In defense marketing speak, these drones can work 'individually, 
collaboratively and spontaneously' to perform ISR (Intelligence, Surveillance and Reconnaissance) or 'break off and go kill something' (Tucker, 2015).

Much more than just 'killer robots,' as campaigners call them, military drones rely on a complex infrastructure that includes operation trailers, computer hardware, remote satellites and data processing software capable of crunching information the human mind alone could not decipher. Each kill decision goes through a hierarchical chain of command involving officers, analysts and legal teams. Asaro calls drone operations a form of 'bureaucratized killing' because it has 'an elaborate and intentional bureaucratized structure' that involves 'self-conscious processes and efforts at rationalization' (Asaro, 2013: 3). Tracing changes in militarism alongside broader changes in the workforce, Asaro shows how computerization and technocratic management seep into soldiers' lives.

This bureaucratized killing attempts to perform what Haraway calls the god-trick achieving the "vantage point of the cyclopean, self-satiated eye of the master subject" (Haraway, 1988: 586). This 'dream of a vision without limit' that can peer 'onto distant galaxies' uses its accumulation of information and surveillance as evidence to 'pride itself on its "objectivity"' (Haraway, 1988: 586). Shaw and Akhter make the connection between Haraway's god-trick and the proliferation of drones, arguing that 'this disembodied visual logic is perfected in the doctrine of airpower' which operates with a colonial logic of 'us' in the sky, versus 'them' on the ground. The drone performs this logic through its 'digital worldview of targets that dismisses ambiguity' (Shaw and Akhter, 2012: 1496).

Yet, of course, while the apparatus of the drone performs this god-trick, they can never achieve the totalizing knowledge they seek. In fact, some claim that up to $98 \%$ of drone casualties are civilians, a success ratio of 50:1. The secrecy that surrounds 
information on how targets are determined becomes another 'tool of information control' (Zulaika, 2012). This myth or fantasy of perfect control is always haunted by the messy realities of bodies and lived environments. There are the more mundane technologies (bright screens, an array of buttons, operating chairs sat in for hours at a time, often in windowless trailers, and plenty of caffeine) that contribute to drone operation, as well as routine operations involving mechanics, ground crews, health and safety checks (Asaro, 2013).

Together this 'vibrant matter' of the drone as human-nonhuman entanglement has what Bennett describes as a distributed agency (Bennett, 2010). Likewise, the drone assemblage can be affected by weather, temperature, wind speed, electrical malfunction and the presence of other airborne structures and aircraft. In addition, as ethicist Robert Sparrow makes clear, accountability for what killer robots can do also rests with the robotics engineers and computer programmers who build them, many of whom have become addicted to military funding in a time when research-funding budgets are slashed elsewhere (Sparrow, 2012).

Of course, while military drones are most commonly associated with the term, not all drones are optimized for violence. There are also surveillance drones, pest control drones, extreme photography drones and conservation drones. Designers have dreamed up prototypes for paparrazi 'selfie' drones and sports buddy drones. The announcement of future Amazon home delivery drones resulted in viral content and commentary spread across social media. Yet, both ideologically and in political economic terms, military drones dominate. I return to this drone hegemony, and to those 'other possible drones' later in this analysis. 


\section{From Cyborg Feminism to Drone Feminism}

In efforts to contribute to the imagination of what drone feminism might be, in this paper I turn back to Western feminists1980s anti-nuclear activisms. I map out an activist history of feminist cyborg figures, examining how women in the anti-nuclear movement combined affect and techné, creating innovative images of, and tactics for, resistance to militarism. My analysis draws primarily on writing and imagery produced by women living at the Greenham Common Women's Peace Camp in Newbury England, the largest of the peace camps resisting nuclear proliferation in NATO countries. The materials I analyze were gathered through archival research conducted over a three-year period in England. Materials include programs from mass demonstrations, songbooks, journal entries, camp newsletters, press releases, radio interviews, letters to the editor in local newspapers like the Newbury Weekly News and publicity pamphlets. In addition to primary materials produced by Greenham protesters, I draw from secondary texts that contain writing by and about Greenham women including magazine articles, newspaper articles, and documents from related organizations and events.

I focus on these 'camp-based' artifacts to examine how the physical environment and community of the protest camp, situated around a military base, affected women's symbol and myth-making practices. Protest camps often become 'laboratories of innovation,' convergence sites at which different ideologies and experiences intermix, yielding new tactical repertoires (Feigenbaum, Frenzel and McCurdy, 2013). I argue that from the place of the protest camp, Greenham women's 'cyborg writing' arose through their material entanglements with the technologies and environments of the military base. 
In their efforts to challenge, undermine and reveal the national and imperial myths upon which nuclear proliferation is based, protesters re-imagined technological possibilities based upon their visions of global accountability for 'earthly survival.'

As part of this activist mapping, I look at how women's creative symbolic practices and their use of tools challenged the dichotomous constructions of women peace activists' relations to technology, such as the binaries of nature/technology, organism/machine and human/animal. Here I return to the anti-nuclear activisms at the heart of Donna Haraway's feminist cyborg to discuss how Greenham women interwove symbolic attributes culled from both goddess and cyborg imaginaries, developing figur es such as Cybil the snake and the 'Metal Goddess'. Throughout this analysis I use Greenham women's craft-based activisms as evidence of how the production of 'symbols' requires embodied engagements with technologies, whether pencils, paper maché, knitting needles or scraps of wire. These embodied engagements are central to an activist articulation of feminist practice that seeks to intervene in the infrastructures and systemic operations of militarism.

As women at Greenham did not refer to their own practices as 'cyborg feminism,' I apply the term both loosely and retroactively in efforts to map an activist history of feminist cyborg figures that can offer insight into their current and future influences on social movement practice, particularly around the proliferation of drone technologies. More than a feminist coding strategy (Laware, 2004) or the retrieval of a lost emotional body (Young, 1990), Greenham women's 'material-semiotic practices' were manifested in particular engagements between bodies and objects that re-imagined feminist subjectivities and reoriented the meanings and uses of technologies (Haraway, 1998: 218). ${ }^{1}$ By examining Greenham women's symbolic, technological and myth-making practices 
through the lens of cyborg scholarship, I argue that women's writing, drawing and crafting of 'disobedient objects' was a place-based practice of resistance through which they mobilized a de-militarized vision of the present and future (Flood and Grindon, 2014).

\section{The (Lost) Activism of Cyborg Feminism}

In the 1980s, Donna Haraway's 'Cyborg Manifesto' challenged the 'organicism' of ecofeminist and pagan feminist movements that constructed 'nature' in opposition to 'technology'. Offering an alternative, Haraway claimed the 'cyborg' as a potential feminist figure. The cyborg, or cybernetic organism, is marked by 'the breakdown of clean distinctions between organism and machine and similar distinctio ns structuring the Western self' (Haraway, 1991:181). For Haraway, both Goddess reclamation practices and cyborg figurations were products of 'the machines and consciousness of late capitalism' (Haraway, 1991: 174). What distinguished cyborg figures from Goddess figures is that while the Goddess clings to nature in opposition to technology, the cyborg breaks down distinctions between the 'natural' and the 'technological' in order to challe nge systems of domination (Haraway, 1991: 174).

Since its publication nearly thirty years ago, this tension between the organic and technological has dominated discussions of Haraway's manifesto. With the birth of internet-based cyberfeminisms of the 1990s, the feminist cyborg's roots in women's antinuclear activism at the end of the Cold War era became largely eclipsed. Little was written about the historical, political or cultural relevance of the cyborg in regard to feminists' antimilitary activism. Instead, critics of cyberfeminism and Haraway's manifesto often saw the cyborg either in opposition to feminist projects invested in re-valuing the earth's eco- 
systems, or as an incompetent model for collective feminist activism in the face of increasing biotechnological controls and bodily surveillance (Stabile ,1994; Klein, 1999)². Whether it was a result of Haraway's critical analysis or her poststructuralist approach, the emancipatory constitution of Haraway's cyborg became frequently heralded as a technozealot's fantasy (Wajcman, 2004). ${ }^{3}$

As 'Haraway' became synonymous with 'the feminist cyborg,' both the nuance and subjects of Haraway's original analysis were frequently lost. The cyborg was attributed (or filled up with) a variety of new meanings that at times bear little resemblance to Haraway's work. As the feminist cyborg moved through various disciplinary iterations, its political context and content was often not referenced. Offering insight into this process, Clare Hemmings found in her analysis of citations in feminist journals that Haraway was frequently evoked as the mark of a poststructuralist turn away from the purported ly naive essentialisms of feminism's past (Hemmings, 2005: 125). Hemmings argues that Haraway, along with Gayatri Spivak and Judith Butler, 'are celebrated for pointing to the failures of an 'early' feminist emphasis on sisterhood' (Hemmings, 2015: 130). This abstracts them from the political terrain of feminism-particularly from feminism as an activist practice. As Hemmings writes, they are 'split from their own legacies within feminism, symbolically, textually and politically situated as 'other' to and 'after' that imagined past' (Hemmings, 2005: 131).

For Haraway, this results in a dislocation of cyborg theory from feminists' antinuclear activisms of the early 1980s. Haraway reflects, 'What I was trying to do in the Cyborg piece [around the question of nature/technology] is locate myself and us in the belly of the monster, in a techno-strategic discourse within a heavily militarized 
technology' (quoted in Penley, 1990: 12). At the time, re-claimed Goddess mythologies were heavily influencing white Western feminist's activism. Neo-Paganism and other spiritual feminisms (Epstein, 1991) shaped the direct action movement against nuclear weapons and nuclear power. Haraway's cyborg offered an alternative proposal for a 'techno-strategic discourse.' Relying heavily on feminist science fiction and writings by women of colour, Haraway imagined alternative languages, images and myths (culled largely from feminist science fiction writing) through which feminist activists could respond to 'militarized technology' (Penley, 1990: 12). Feminist Cyborg theory offers a way of understanding not only how political subjectivities are transformed through the production of language, but also how language practices are intimately bound up with the ways we relate to technological objects and to the technological environments in which we live.

\section{Cyborg Feminism in the 'Belly of the Monster'}

There are few places as militarized as a nuclear military base. In 1981 the Greenham Common RAF military base became the first British site to store US nuclear cruise missiles, making it a prime protest target for the UK's active anti-nuclear movement. ${ }^{4}$ On September 5, 1981 a group of women ended their march from Cardiff, Wales outside the Greenham Common United States Air Force base in Newbury, England in protest of the 1979 NATO decision allowing US nuclear cruise missiles to be housed at military bases in Europe. The group of around 35 marchers, mostly women, demanded a televised debate with the Ministry of Defense over the decision to site cruise missiles in England. The women's request was not granted, so they refused to leave. As supporters and supplie s came in, an 
encampment emerged. In 1982 the camp became women-only and adopted the name 'Greenham Common Women's Peace Camp.' By the end of the year protest events at the camp drew thousands of women and international media coverage.

Anne Seller wrote in 1985, 'At the [Greenham] fence you can see the immense might of the nuclear state: acres of coiled barbed wire, immense concrete structures, columns of armed men in pathways between the barbed wire' (Seller, 1985: 27). The perimeter fence marked the space of the protest encampment and the site of women's protest actions. ${ }^{5}$ Former Guardian newspaper defence correspondent David Fairhall wrote in his book on Greenham, 'To a remarkable extent, it was the physical nature of [the fence] that determined the protest' (Fairhall, 2006: 105). At the time the Ministry of Defence considered a number of proposals to further secure the military base from protestersincluding creating a land swamp, shrinking the perimeter and electrifying the wire. In the end they settled on extra guards and more rows of razor wire (Fairhill, 2006: 107-108).

Women's lives at the camp were never separate from the military life of the base. Women constantly interacted with soldiers and the physical materials of the site. At the same time, women's camps were set up on the common land surrounding the base - a habitation that included gorse, heather and bracken. Tim Cresswell (1996) described this juxtaposition as a disruption of the "hegemonic-geographical order," referring to the chaotic, non-hierarchical camps at Greenham as a "heretical geography" that transgressed normative geographic space of both the military base and the Newbury country-side (Cresswell, 1996: 100). It was this transgression, the messy yet tactical slippage of 'nature' and 'technology' that drew Haraway to the women of Greenham Common. 
In her manifesto, Haraway specifically identified Greenham Common women's analyses of the military-industrial complex, establishment of non-hierarchical communication infrastructures, and their tactical methods for intervening in the storage and transportation of cruise missiles. Haraway described how cruise missiles were more effectively 'blocked' by the creative resistance practices of Greenham women, than by "the militant labour of older masculinist politics" (Haraway, 1991: 153). Rather than rely solely on marches and petitions, Greenham women put their bodies in the way of military infrastructure. They put locks on military entrance gates, had sit-ins on the road, damaged military property with colorful graffiti and engaged in on-site performances that continually drew media attention to the presence of these missiles on British soil. Here Haraway notes how Greenham women used symbolism and metaphor in place of conventional masculinist political discourse to interfere with the operations of military power. Through embodied, collective, material-semiotic practices, Greenham women constituted part of what Haraway saw as an emergent feminist cyborg politics.

\section{Greenham's Cyborg Feminisms}

At Greenham protesters learned to critically read the patriarchal, military-industrial languages through which the base personnel, police and court system operated together. In the following passage, Fran Bradshaw and Teresa Thornhill (1983) articulate the ways in which webs of power bring objects, people and institutions into networked relationships in their discussion of the Easter blockade on March 31-April 1, 1983. During the first day of action there was a Campaign for Nuclear Disarmament (CND) blockade of the base, 
followed the next day by a human chain linking the base and the Aldermaston weapons manufacturing plant. Bradshaw and Thornhill reflected in an article for Spare Rib: At Greenham we see two faces of militarism. During the Easter blockade, the police on the ground treated protesters as if we'd all come for a family outing; while in the sky, huge troop helicopters ferrying in soldiers from other bases reminded us of the sophisticated technology which is at the disposal of the army. In the background, there were mounted police and riot shields, and Holloway prison had cells prepared. These were scarcely used at Easter, but we should be under no illusions that they won't be used if 'necessary' (Bradshaw and Thornhill, 1983: 61).

Here Bradshaw and Thornhill describe how helicopters, mounted police, riot shields and prison cells comprise the 'hardware and tactics' of militarism. The police, court system and soldiers are all seen as part of a 'matrix of domination' that is capable of renegotiating how objects and bodies police the Greenham protests. Through such sophisticated understandings of these systems of power, Greenham women created tactics to intervene, to block and to harness this power. To do so, they generated their own symbols, figures and myths-out of pens, paint, glue, wire, fabric, needles, wool and stolen bits of chain-link fence. In the next section of this paper I look in particular at three feminist figurations of the web, the snake and 'liberating metal' as they relate to the emergence and proliferation of cyborg subjectivities in women's activism and anti-militarism campaigning.

\section{Webs of Power/Webs of Resistance}

Greenham women read webs of power and responded by creating webs of resistance. The metaphor of 'building a web' and being connected to each other in a 'web - 
like structure' populated Greenham women's speech and writing. ${ }^{6}$ Alison Young describes Greenham women's webs as showing 'connections between women or between ideas; [a web] can be begun at any point or at any time; each single strand is weak and fragile, yet when interwoven it is strong, beautiful and efficient' (Young, 1990: 38). In line with Young's reading, Sasha Roseneil (1999) writes that, 'the web was a symbol of women's collective power, seemingly fragile, but actually very strong' (Roseneil, 1999: 179, ft39). This practice of creating webs of resistance-and its representation through symbolic spider figures — can be seen in promotional communication for the 1985 'Widening the Web' December event which crystallized women's efforts to make connections between issues of nuclear militarism and (among other things) anarchy, USSR dissidents, violence against women, apartheid, imperialism, nuclear testing, women in prison, racism and animal liberation. The demonstration booklet for this event showed the image of a web being stretched out by a number of different women, each pulling on a strand that comes together in the centre. Roseneil (1999) also discusses the notion of the web in relation to Greenham's infrastructure, showing how the organization of the camp and its support networks constituted 'a non-hierarchical, intricate pattern of individuals and groups, joined together by almost invisible yet strong connecting threads' (Roseneil, 1999: 175). [insert Fig. 1] 


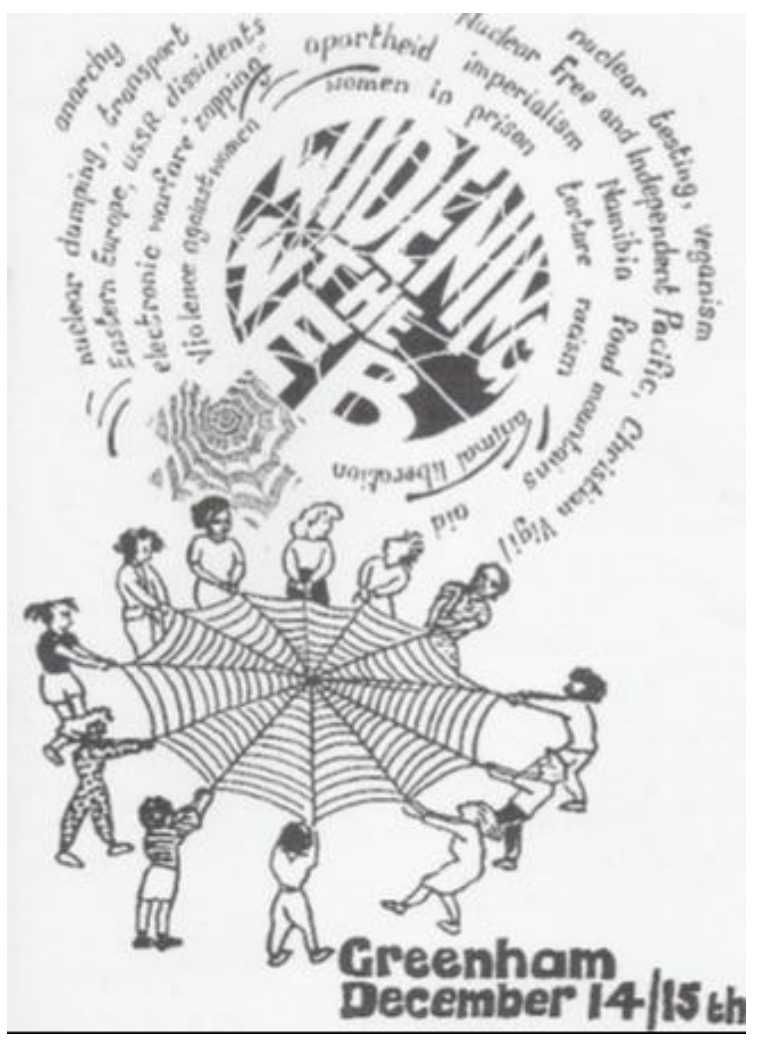

Figure 1: Cover of pamphlet, widening web

Each of these invocations and understandings of webs at Greenham resemble Haraway's conception of weaving found in her cyborg manifesto. 'Weaving,' for Haraway, is the practice of oppositional cyborgs. It is the differential movement/s of cyborg collectivities capable of blocking, harness, redirecting and appropriating flows of patriarchal and capitalist power in the "integrated circuit" (Haraway, 1991). By the time Greenham women were actively camping onsite, weaving practices had already been explicitly put to activist use against militarism. A few years before the Greenham encampment began, a Vermont women's affinity group named the Spinsters had woven shut the gates of a nuclear power plant using wool, string and rags (King, 1983). At the first meeting for the Women's Pentagon Action, this story of the Spinsters was shared with the group of event organizers. Then, at the 1981 Women's Pentagon Actions, the Spinsters and 
others wove together entrances to the Pentagon (King, 1983). Images and anecdotes of these weaving actions spread through transatlantic ecofeminist, anti-nuclear and peace networks. These weaving actions were passed along by and to Greenham participants, influencing and inspiring similar tactics at the camp - and providing an excellent example of how movement ideas travel across time and place.

Just as the Vermont Spinsters used wool, string and rags to construct obstacles for authorities, Greenham women's webs became, at times, physical barriers, 'baffling the policemen and court officials' (Young, 1991: 38). On October 5, 1982 women set out to obstruct the laying of sewage pipes into the base. Reprinted in Women at the Wire, Jane's diary entry for the day reads:

First of all we occupied the site where they wanted to begin digging. For an hour about 20 of us wove a huge web of wool and string across the whole area. We entangled ourselves in it, some women sat amongst the threads, others lay beneath it. We were addressed, in turn, by policemen who told us that we were obstructing the contractors going about their lawful employment and therefore our behaviour was likely to cause a breach of the peace. Then they began to drag us off very roughly, ripping and untangling themselves from the web (Harford and Hopkins, 1984: 70).

As these accounts of 'weaving' activities and actions make clear, webs were not simply a metaphorical device used to capture women's connections to each other. Nor were they only a means by which to describe women's diffuse, horizontal communication networks. Rather, webs, like Greenham women, 'were everywhere.' Threaded into fences, wrapped around trees, sketched across promotional flyers, webs were an essential part of 
Greenham's (un)common language. At once, an embodied rhetoric, an ironic gesture and a cyborgian technological engagement, Greenham women's many web-weavings called for a new conception of collectivity. It offered a challenge to the 'informatics of domination,' attempting to weave together both oppositional ideologies and tactics (Haraway, 1991: 162).

\section{Cyborg Snakes}

Snakes were another of the most celebrated animal figures at Greenham. They appeared frequently in women's poetry, drawings, cartoons and various prose writing. Snakes adorn the cover of the Women's Peace Camp February 1983 newsletter. These snakes are in double spirals: a symbol of both snakes and the Goddess, representing the balance of the seasons. The back cover of this 'newsletter,' a 32 page A4 booklet with a double staple binding, is decorated in spiral snakes. Even the ' $W$ ' of 'Women's' is fa shioned as a snake. The extensive table of contents lists three features on snakes. These include camper Jayne's reflection on a direct action involving women entering the base underneath three giant fabric 'snakes'; a graphic story of the snake action; and a proposal for upcoming 'Snakes and Ladders' actions.

In the 1970s and 1980s, feminist reclamations of the snake drew from its history in Greek mythology and Minoan culture. In Greek mythology the snake was a symbol of Athena, the Goddess of wisdom. In Minoan culture, the Snake Goddess is thought to have been connected to the Mother Goddess or Earth Mother. The snake was also a symbol of rebirth. The shedding and regeneration of a snake's skin signified the seasons and the continuous renewal of energy and knowledge. With the rise and spread of Christianity, 
these meanings attached to the snake were largely suppressed (Walker 1988). Buffie Johnson writes, 'The serpent serves as a metaphor for the impenetrable manner in which our lives change, twist, and renew themselves' (Johnson, 1988: 128).

This sense of renewal and of celebrating the changing seasons took on a particular significance at Greenham. Whether women were already inclined toward Pagan and Goddess celebration practices, or discovered them for the first time at Greenham, living outdoors through rain and snow with constant pressures from police, soldiers, media and visitors, gave 'renewal' and 'regeneration' whole new meanings. As camper Liz Galst put it, a connection to the earth 'is good to have if you're living in the mud in the winter' (personal correspondence). Galst was among those who did not overtly engage in Pagan and Goddess rituals, though was drawn toward a deeper appreciation of the cycle of the seasons, the phases of the moon and generally being in touch with your environment, which came from living outside, especially amidst harsh conditions. Alison Young argued that for Greenham women the snake's 'ambiguity is a source of power and potential for resistance to the dichotomy which presumes images to either possess or lack meaning' (Young, 1990: 38). Greenham women did not deny the snake's associations with fear or poison, rather they were 'choosing to play up certain forgotten or lesser known aspects' (Young, 1990: 37). Greenham women's use of these symbols was an attempt to confront and subvert the meanings ascribed to them by dominant culture.

On the day of Defense Secretary Michael Hestletine's visit, February 7, 1983, over 100 women decided to enter the military base as snakes in order to show how easy it was to break past security. These snakes were fabric and paper mach é creations worn over women's heads that moved into the base and along the base's runway. Greenham camper 
Gillian Booth's 'A Snaky Story' offers a five page graphic story of the adventures of snakes Cecily, Rosie, and Sybil as they entered the base. Booth narrates her story in swerving handwritten text around drawings of women holding up the snakes. The story ends with an image of Greenham women in a police van after Sybil was arrested. The text reads:

We amused ourselves further by chalking anarchy and peace women's signs on a few patrol and riot helmets while being held in a van owned by men who call themselves 'POLICE'. We saved Sybil's head, which accompanied us to Newbury 'Police' Station and was released when we were after the charges against us were dropped.

[insert Fig. 2]

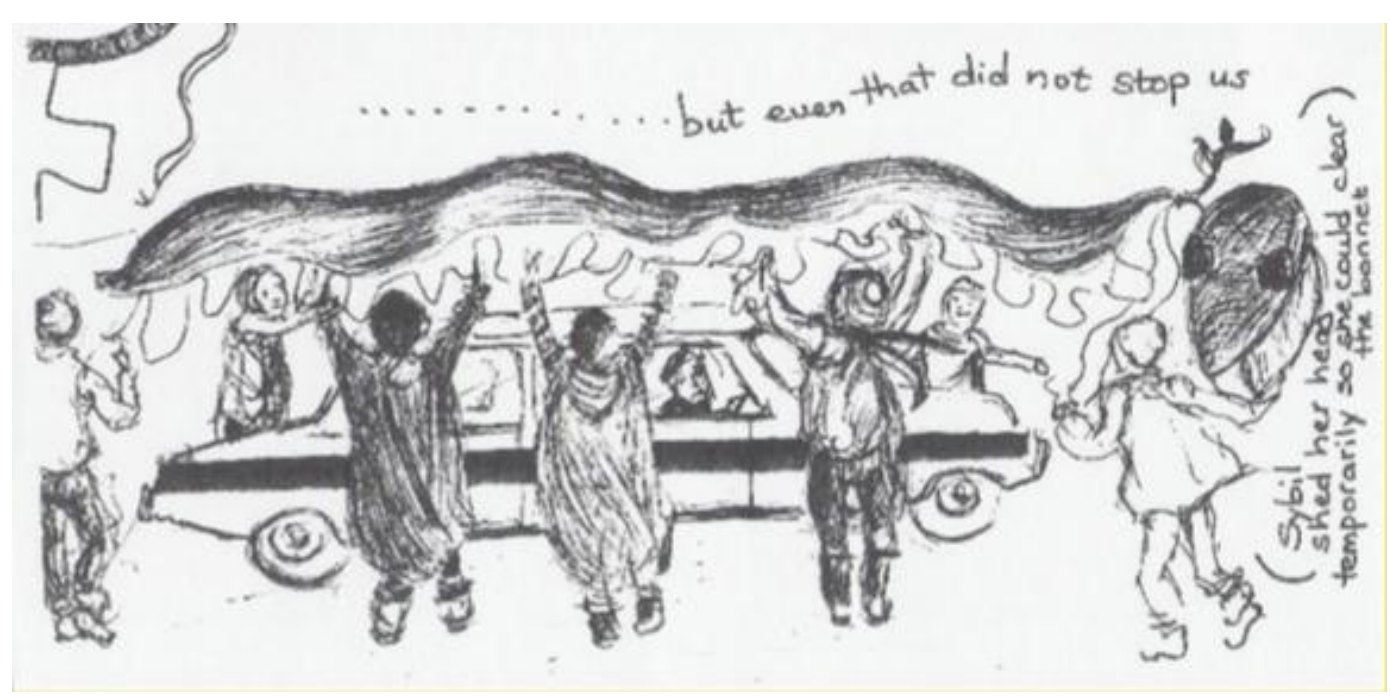

Figure 2: Gillian Booth's "A Snaky Story" from Greenham Women's Peace Camp Newsletter, 1983

In Booth's story the snakes stand in for the groups of women beneath them, slithering through the base and along the runway. The bodies of the women and the animals mesh together. Yet these snakes are not organic. They are technological constructions made from women working with paper, flour, water, glue and paint. They were part mythic, part real; 
part human, part 'animal' — crafted from physical engagements with the materials and signification systems of the military base. The snakes, as protest tactics, helped enable women to enter the military base, revealing the myths of 'national security' encoded into perimeter fences and guard towers. In this sense the Greenham snakes also evoke the 'trickster figure' prominent in Haraway's work. The trickster, in Haraway's lexicon, is both a mythic device and a methodology for reading the world (Haraway 1997). As Greenham women literally used these snakes to trick authorities, they combined strategic readings of how base security operated with tactical maneuvers for sliding over, under and through the holes or cracks in its security system.

Booth describes how these moving snake-women befuddled the police. As the women took on the body of the snakes, the police became confronted with a situation outside their protocol. In order to arrest the women, they first had to apprehend the snake. Likewise, scribbling anarchist, peace and women's signs onto the police helmets recodes the symbolic power of the uniform as a marker of authority, revealing its function as costume. Yet, these 'men who call themselves 'POLICE' are, of course, still legitimated to arrest, detain and harass the women. While it does not, in itself, undo institutionalized relations of power, the dislocation of the policemen from their authority opened up important possibilities for women's protest action.

\section{Metal Goddesses}

Greenham women's everyday encounters with the technologies of the base led many women to formulate analyses of how material resources - such as uranium and other metallic elements-were extracted from the earth and used to make weapons. These 
analyses often drew together ideas from Goddess and spiritual feminisms with an explicit discussion of tools and technologies. Appearing in the 1983 Rainbow Dragon Festival protest event booklet was an anonymous prose piece introducing the figure 'Goddess of Uranium' or 'metal Goddess':

Metal is a natural element-use and abuse of metal is out of control - the core of the earth is believed to be metal - the earth reclaims metal, from her core, for her own. The Goddess of uranium is ANGRY. I had a tendency to ignore metal, until working on the dragon idea and looking into a Chinese horoscope book, about fire controlling metal (the dragon breathes fire) I began thinking about how the combination of male power and metal was a very dangerous thing and instead of disliking metal itself, I began thinking of it as a mis-used natural element ... Patriarchy has gone as far as it possibly can with metal ... e.g. with all the weapons and the control over physical life that it has.

This piece expresses how the author went from 'disliking metal itself' to 'thinking of it as a mis-used natural element.' Here she makes a distinction between the essential nature and use of materials. Metal is seen as an element that is constructed not only by its chemical composition but by the values and meanings that shape its use. The dominant values and meanings associated with metal can thus change along with people's practices. The figure of the metal Goddess is created as a way to imagine alternative uses of this resource.

Offering another account of metal, Sarah wrote an article entitled "Liberating Metal" in the Greenham Women's Peace Camp Newsletter:

Metal is a compulsive substance exciting to cut and shape, to work with. Perhaps it is this excitement of metal that has sparked men to use it and use it. They have 
wanted to have her power, to make their weapons. With this use of metal the earth is not happy. We can make other things together. Exciting, useful, powerful, lifeenhancing metal things.

In Sarah's writing metal is referred to with a female pronoun, drawing a connection to the earth as a living being. Rather than seen as a static resource for man to use at his will, Sarah views metal as an active, alive technology, a 'compulsive substance.' She argues that its potential uses should not be defined or determined by military interests. Reclaiming the earth and its resources as part of a larger ecosystem, Sarah imagines alternative possibilities for engaging our technological world.

7

As daily living at Greenham required women to interact with both technologies of the base and the scarce resources of the camp, women were regularly involved in developing their own liberatory technologies (see Bookchin and Kornegger in Dark Star Collective, 2002). Many women quite literally 'liberated' metal from the fence as well as from shopping carts and scrap piles, in order to transform and build household technologies. Sasha Roseneil describes these practices at length:

During periods when evictions were infrequent a number of women, particularly at Green Gate, devoted themselves to making furniture from scrap wood and bundles of sticks. Women built mobile kitchens on wheeled pallets in order to be able to save food from the bailiffs ... Women at Green, Blue and Orange Gates built earth ovens to bake cakes, breads and puddings. Others forged grills and sandwich toasters from pieces of the fence which they had cut down. At Green and Blue Gates showers were rigged up from trees (Roseneil, 2000: 108). 
Many of the apparatus, utensils and other tools Roseneil describes here were depicted in illustrations in Greenham newsletters. The "More June News" edition of Green and Common contained a "Do It Yourself Hints" series of drawings. The four-panel strip describes 'How to Make a New Grill'. [insert Fig. 3]

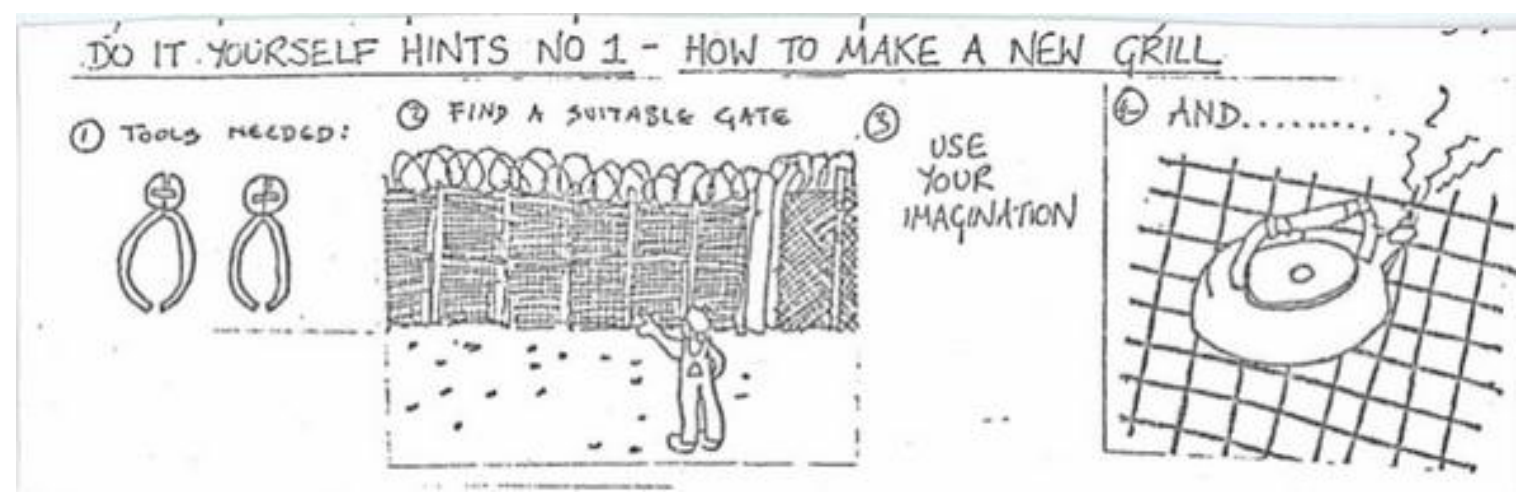

Figure 3: Do It Yourself Guide to Remodeling the Perimeter Fence

One begins with bolt cutters, then finds a 'suitable gate.' Rather than telling you what to do through either text or illustration, panel three says, 'Use Your Imagination.' This is followed by a fourth and final panel that depicts a steaming teapot on your new grill. While offered more as a tongue-in-cheek rendition of women's practices than a practical instruction manual, the skill-sharing and do-it-yourself ethos of Greenham is well captured here (as is the incessant making and drinking of tea). As women use pieces of the military base's security fence to construct a cooking grill, the metal is simultaneously transformed as both object and symbol. From a signifier of militarism and enforced border s, the metal becomes a signifier of warmth and home. This transformation is not a rhetorical recoding of the fence's materiality, but the result of a specific technological engagement in which women's refusal to accept the legitimacy of the fence as private military property enables them to re imagine the possible uses of the metal that surrounds and encloses the base. 
It is crucial here that an apparatus of militarism is directly harnessed. Creating cooking grills, mobilizing spider's web metaphors and crafting paper-maché snakes are not in themselves resistant or disobedient practices. Rather, resistance is the act of direct intervention into the apparatus of the military base as simultaneously an operational and symbolic element of the war machine. As Greenham women turned these symbols of webs, snakes and metal goddesses into actions, and their actions into symbols, they developed new ways of engaging technological objects and environments. Greenham women's uses of spiritual symbolism and Goddess mythology gave their protests against technological warfare and environmental destruction a distinct political resonance. Many women, unfamiliar with feminist activism, were drawn to Greenham protests because of their rich, emotive culture and passionate energy. Reclaimed mythic figures confronted the 'rational', scientific language of Left politics, carving a space for the creative, spiritual dynamics of activism.

\section{Toward a Drone Feminism}

Drawing from the extent to which Greenham women's practices mobilized, troubled and challenged people, it is worth asking, are drones today's cyborgs? For Haraway the cyborg was 'the illegitimate offspring of militarism and patriarchal capitalism' (Haraway, 1991: 151). Likewise, the drone is a manifestation of these power structures. Yet it is of a new generation, born in the age of the algorithm. The drone furthers the cyborg's dream of absolute knowledge, as it emblemizes fantasies of data-driven power in a time of increasing environmental vulnerability and capitalist collapse. The drone carries with it the promise of the god-trick, an all-seeing machine that can always generate more: more information, 
more cost-benefit savings, more surveillance, more domination-and hence, more remote executions. This obsessive quest to create the perfect 'killer robot', capable of knowing, finding and executing targets, forms the basis of the Campaign to Stop Killer Robots. Through petitions, press work and international campaigning the coalition has done much to raise awareness of the humanitarian, ethical and legal implications of existing drones and the proliferation of so-called 'fully autonomous' aerial vehicles on the horizon.

While drone feminism may celebrate the successes of this campaigning, its primary focus is not on the 'good' drones versus the 'bad' drone, or military versus civic drones, as is so common now in media reports and in the business plans of technology companies with their shiny marketing materials and exuberant flight demos. The vilification of the 'bad' drone, coupled with praise for the 'good' drone provides a useful NGO campaign strategy. Yet by turning focus toward the violence of the machine, such strategies further fetishize the drone. How can drone feminism instead beco me attuned to all drones as entangled in operative systems, in human and nonhuman drone infrastructures. A critical understanding of the infrastructural and process-driven aspects of drone systems is fundamental to understanding how these systems are fueled by a neocolonial logic for administering life and death (Vasko, 2013). How can accountability for this remotely operated violence be distributed beyond the most visible contours of either the operator or the vehicle, without being divvyed out to the point of unaccountability?

Rather than reproduce binaries that rely on fantasies of individuated autonomy, drone feminism performs feminist readings of power that actively unveil the operative systems and logics of military drone violence. To help create interventions into drone practices and infrastructures, drone feminism demands analyses of power as it operates in 
ways that are gendered, imperial, racialising and Orientalizing. Drone feminism locates the ways that these manifestations of power intertwine with pursuits of profit and data-driven phallocentric dreams of perfect knowledge. In reading these webs of power, drone feminism strives to understand the physical and psychological impacts that remote-killings have, damaging, re-imagining and traumatizing soldiers 'at home,' while enacting regimes of atmoterrorism abroad-violence from the air that creates daily fear for people and their environments(Sloterdijk, 2009; Blanchard, 2011; Shaw and Akhter, 2012; Asaro 2013). From the situated position of Western imperialism — with its violent trajectories of administering life and death - drone feminism asks, what does it mean to actively resist drone militarism today? (Vasko, 2013).

\section{Reading Drone Webs of Power}

Contemporary drone assemblages are comprised of sonic surveillance, precision GPS location, real-time video feed and a dizzying array of radar's that strive to perform the god-trick of universal vision. These technologies are researched and developed through powerful webs that include universities, government committees, laboratories, legal firms, and increasingly PR companies. As these connections become further entangled through corporate R\&D partnerships (i.e. Facebook, Google and Amazon have all bought drone technology companies in the past few years $)^{8}$, today's matrix of militarization that feminists must navigate and resist has permeated evermore dimensions of our increasingly technologized lives. As Shaw and Akhter argue, the technologies that drones engage to target people are advanced versions of those used in our everyday digital lives. 'GIS and 
GPS programs are no longer alien technologies used by armies and government agencies, but shared everyday practices' (Shaw and Akhter, 2012: 1496).

But to read today's drone webs of power requires an understanding that goes far beyond the social media of our daily lives, challenging us to engage with how 'big data', machine learning and algorithmic automation intersect with more traditional modes of militarized power and technology. Today the 'god-trick,' or myth that drone infrastructure can translate all the data it collects into perfect knowledge, forms what Haraway saw as 'the central dogma of phallogocentrism' in cyborgian militarism (Haraway, 1991: 176). The Informatics of Domination rests on information as quantifiable elements 'which allows universal translation, and so unhindered instrumental power' (Haraway, 1991: 156). Today, this fallacy of code is foundational to the belief that quantifying data can generate undoubtedly guilty and deserving targets for execution. Because algorithms can handle information that is too complex and to large for human minds, in drone logics, trust is handed over to the machine (or to processes of machine learning) to predict the future, telling us not only what to buy, but who has to be killed.

\section{The Impacts of Remote Killing}

While drone infrastructures rely on large networks of people, fewer people have to directly confront the reality of aggressively administering death. This is a fundamental part of the logic and ideology of the drone-system: the less soldiers sent home dead, the less public outrage over illegitimate killing. The majority of public opinion in favor of drones in the United States is maintained through sanitized stories of expert military bureaucracy and its high powered data machines at work. This is a process of making remote, of 
increasing the distance between 'us' and 'them': if there is no draft, and fewer children or siblings going off to face a bloody death, then there is far less impetus for outrage.

If the cyborg asked us to rethink how closely intertwined the body and machine had become, then perhaps the drone challenges us to understand how that cyborg relation has become increasingly intimate, while at the same time, the proximity between the body and the machine can be ever more distant. As Blanchard argues, 'images of warrior masculinity undergo a reconstitution when those prosecuting the war are tele-present, yet operate at a physical remove' (Blanchard, 2011: 160). The psychological effects of this administration of death taking place at home rather than 'off at war' alters both the domestic relationships of soldiers, as well as where they fit in masculine narratives of bravery and heroism (Blanchard, 2011).

The posthuman entanglement of the operator and the drone is riddled with affect. Bourke argues that in his attempt to insure 'combatative dominance, the posthuman drone pilot has to allow the machine to get under his skin; he has to feel the machine in order to effectively navigate or fly it' (Bourke, 2014: 31). Looking at literature on soldiers' use of unmanned ground vehicles in Iraq, Blanchard similarly found that the men formed emotional connections with their robot assistants, masculinizing and anthromorphizing them by giving them names, battle commendations, and their own war stories (Blachard, 2011).

Yet, of course, it is not just the US soldier who feels the drone. While exact figures are both strategically undisclosed and difficult to record (a recurrent issue in the increasing turn to data as supreme knowledge), current estimates put the death toll of drone strikes between 4000-6000. As drone operators press buttons and make decisions, people 5000 
miles away live in an ongoing state of fear, subject to constant surveillance and the threat of attack from unseen weapons flying 5,000 in the air feet above them.

Drawing on two major research reports that involved a total of 290 interviews, Shaw summarized key findings about living in drone attack areas. Interviewees discussed 'double tab' strikes, where civilian first responders who attend to drone victims are then fired upon by attack drones, often leading to more civilian deaths (Shaw, 2013). Considered sites of increased targeting, many people avoid community gatherings like funerals and tribal meetings, some keeping their children home from school for fear of attack. The constant hovering of drones leads to 'a deeply entrenched psychological malaise' and breeds resentment and anger toward the United States and its NATO partners that operate drone executions (Shaw, 2013:6). There is evidence that drone strikes are increasing recruitment to violent non-state groups, perpetuating anti-American sentiment and delegitimizing international law (Shaw, 2013).

Zulaika compares the drone system's pursuit of would-be terrorists to witch hunts, to argue that fictionalizing the myths of terrorism can destabilize its realis trepresentations (Zulaika, 2012: 66). Such practices of writing alternatives must exist in dialogue with activist techné. Drone feminisms, like the cyborg feminisms of anti-nuclear activists, must involve 'both building and destroying machines, identities, categories, relationships, space stories' (Haraway, 1991: 181). Glimpses of a nascent drone feminism can be increasingly seen in contemporary activist practice, as people occupy sites of drone operation and infrastructure. Recent resistance includes: fence cutting at the UK's drone operation base RAF Waddington, Swiss activist blockades of a drone presentation at Thun military base in protest against drone deals with Israel, and US protesters' blockade of Hancock airbase 
using giant copies of the UN charter, drone reports and US constitution. This emergent drone feminism can likewise be found in practices that critically monitor and make visible drone systems and their rhetorics, such as. Code Pink's direct actions at bases, museums and government buildings, alongside their Global Drone Watch, the Disruption Network Lab's drone event in Berlin that sought new strategies for visualizing this violence. As Joe Scarry of the No Drones Network puts it:

People are fighting the drones with every means at their disposal: they're fighting drones with plays... they're fighting drones with music... they're fighting drones with film... they're fighting drones with models... they're fighting drones with art... they're fighting drones with local ordinances... they're fighting drones with book tours... they're fighting drones with Freedom of Information Act (FOIA) requests... they're fighting drones with editorials... they're even fighting drones with good ol' persistent journalism... Everyone is working to make a difference the best way they know how (Scarry, 2015).

From the blockades of NATO supply chains in Pakistan, to the US Veterans petitioning for drone operators to step down, drone feminism seeks out solidarity across the drone operation and infrastructural system. It is through the amplification and creative adaptation of these combinations of critique, creativity and sabotage that drone feminist practices in the West can further intervene into its neocolonial logics of administering life and death through drone surveillance and executions.

Fine-tuning activist practice requires new analyses and new languages. Contributing to this, drone feminist scholarship must go beyond a posthumanist embrace of the affective entanglements of body and machine (Burke, 2013). At the same time it strives to offer 
more than a philosophy-boy's-club reading of Foucauldian biopolitics or Agamben's states of exception--so popular in the existing scholarship on drones (Vasko, 2013; Wilkinson ,2013). Enhancing critique, drone feminism seeks to remember its cyborgian legacies, constructing a political economic reading of how the 'administration of life and death' is always bound up in the pursuit of profits and a masculinist drive to see from on top. In doing so, drone feminism attempts to reveal the myriad ways that gender matters in the infrastructures and psychologies of drone executions (Blanchard, 2011), as it offers up new sites and languages for feminist activism.

\section{References}

Asaro, Paul M (2013) 'The labor of surveillance and bureaucratized killing: new subjectivities of military drone operators,' Social Semiotics, 23(2), pp. 196-224.

Bennett, Jane (2009) Vibrant matter: A political ecology of things, Durham, Duke University Press.

Blanchard, Eric (2011) 'The Technoscience Question in Feminist International Relations: Unmanning the US War on Terror' in JA Tickner \& L Sjoberg (ed) Feminism and International Relations: Conversations About the Past, Present, and Future, New York: Routlege, pp. 146-63.

Bourke, Joanna (2014) 'Killing in a Posthuman World: The Philosophy and Practice of Critical Military History' in B Blaagaard and I van der Tuin (ed) The Subject of Rosi Braidotti: Politics and Concepts, London: Bloomsbury.

Bradshaw, Fran and Therese Thornhill (1983) 'Northern Ireland and Greenham Common—connections and contradictions' Spare Rib, August 1983. 
Cresswell, Tim (1996) In Place/Out of Place: Geography, Ideology and Transgression Minneapolis: Minnesota University Press.

Dark Star Collective (2002) Quiet rumours: An anarcha-feminist reader. Oakland: AK Press. Epstein, Barbara (1991) Political Protest \& Cultural Revolution. Berkeley: University of California Press.

Fairhill, David (2006) Common Ground. London: I B Tauris \& Co Ltd Feigenbaum, Anna, Fabian Frenzel \& Patrick McCurdy (2013). Protest camps. London: Zed. Grindon, Gavin and Catherine Flood (2014) Disobedient objects. London: V\&A Publishing. Haraway, Donna (1988) 'Situated knowledges: The science question in feminism and the privilege of partial perspective' Feminist studies, 14(3), pp. 575-599

--- (1991) Simions, Cyborgs and Women. New York: Routledge.

--- (1997) Modest_Witness@ Second_Millennium. New York and London: Routledge.

--- (2004) The Haraway Reader. New York and London: Routledge.

Harford, B and S Hopkins (1984) Greenham Common: women at the wire. London: Women's Press.

Hemmings, Clare (2005) Telling Feminist Stories, Feminist Theory 6, pp. 115-139. Johnson, Buffy (1988) Lady of the Beasts. San Francisco: Harper SanFrancisco

Klein, Renate (1999) in Susan Hawthorne and Renate Klein (ed) Cyberfeminism: connectivity, critique, creativity. Melbourne: Spinifex Press, pp. 185-212.

King, Yenestra (1983) 'All is Connectedness: Scenes from the Women's Pentagon Action, USA' in Keeping the Peace, Lynne Jones (ed) London: The Women's Press, pp. 4063. 
Laware, Margaret (2004) "Circling the Missiles and Staining Them Red: Feminist Rhetorical Invention and Strategies of Resistance at the Women's Peace Camp at Greenham Common." NWSA Journal 16: 18-41.

Penley, C, A Ross and Donna Haraway (1990) “Cyborgs at Large: Interview with Donna Haraway. Social Text 25/26: 8-23.

Roseneil, Sasha (2000) Common women, uncommon practices: the queer feminisms of Greenham. London and New York: Cassell

--- (1999) “The Art of the (Im)possible? European Journal of Women's Studies 6, pp. 161182.

Tucker, Patrick (2015) 'The Navy is Preparing To Launch Swarm Bots Out of Cannons' Defense One 14 April 2015.

Sayler, Kelley (2015) A World of Proliferated Drones. Center for a New American Security. Scarry, Joe (2015) Protests Against Drones Spreading. Available at http://www.worldcantwait.net/index.php/reports-on-protest-resistance/7971protests-against-drones-spreading (accessed 15 June 2015).

Seller, Anne (1985) 'Greenham-A Concrete Reality.' Frontiers: A Journal of Women's Studies 8, pp. 26-31.

Shaw, Ian \& Majed Akhter (2012) 'The unbearable humanness of drone warfare in FATA,' Pakistan. Antipode, 44(4), pp. 1490-1509.

Shaw, Ian (2013) 'Predator empire: the geopolitics of US drone warfare' Geopolitics, 18(3), pp. 536-559.

Stabile, Carol (1994) Feminism and the Technological Fix. Manchester and new York: Manchester University Press. 
Stromburg, Joseph (2011) ‘B.F. Skinner’s Pigeon-Guided Rocket’ Smithsonian.com Available at: http://www.smithsonianmag.com/smithsonian-institution/bf-skinnerspigeon-guided-rocket-53443995/?no-ist (Accessed: 15th June 2015).

Wajcman, Judy (2004) Technofeminisms, Cambridge: Polity Press.

Walker, Barbara (1988) The Woman's Dictionary of Symbols and Sacred Objects, San

Francisco: Harper Collins.

Whitlock, Craig (2012) 'When Drones Fall From the Sky’ Washington Post 20 June 2014.

Wilkinson, Jayne (2013) 'Animalizing the Apparatus: Pigeons, Drones and the Aerial View' Shift, 6, pp. 1-21.

Williams, Zoe (2013) Drones mean RAF Waddington could become a new Greenham Common. The Guardian 7 June 2013.

Young, Alison (1990) Femininity in dissent. London and New York: Routledge.

Young, Iris Marion (2003) 'The logic of masculinist protection: Reflections on the current security state' Signs, 29(1), pp. 1-25.

Zulaika, Joseba (2012)'Drones, witches and other flying objects: the force of fantasy in US counterterrorism' Critical Studies on Terrorism, 5(1), pp. 51-68.

\footnotetext{
${ }^{1}$ Like Haraway, a number of scholars analyzing Greenham discuss how symbolism and myth-making constituted a fundamental part of women's resistance to nuclear militarization. Greenham women were able to disrupt the dominant language culture of the nuclear state, as well as the language of the male-dominated Left. Alison Young notes in her analysis of Greenham that writing poetry allowed women to voice their feelings and bring the emotional body to the fore (Young, 1990: 35-36). While the mainstream media utilized a language that demonized and degraded women, Young argues that Greenham campers, "Attempt[ed] to find a bodily expression ... independent of the negative connotations that femininity can attract" (45). Likewise, Margaret Laware's article on Greenham women's rhetorical strategies describes how protesters' used feminist coding strategies to challenge and undermine masculine symbols of the military (Laware 2004). Along these same lines, Tim Cresswell uses literature on the carnival and carnivalesque to argue that Greenham women brought emotion into spaces delineated as cool and rational, such as the military base and the courtroom. For Cresswell, Greenham women's symbolic protests
} 
disrupted the "hegemonic-geographical order" of both the military base and the Newbury countryside by making visible the grotesque body and objects from private life (Cresswell 1994). Sasha Roseneil also details how Greenham women engaged in signification practices that brought is sues of language and representation to the surface of their political action. 'Against constructions of women as victims, as those who are 'done to' by men and governments or "fought for' by armies," Roseneil argues that, "women at Greenham came to perceive themselves as powerful' (Roseneil 1999, 170). For Roseneil the significance of the sign in Greenham women's politics is evidence of the protests' postmodernity. In postmodernity, 'language and signs are more than merely the media for political messages; they are themselves part of the political process' 1999: 166). Signs and symbols are able to confront, transform and imagine possibilities. They dis rupt dominant language systems by offering alternative ways of marking and making sense of the world. Here we can see direct connections with Haraway's conception of cyborg writing. Each of these Greenham scholars' analyses share with Haraway a concern about binary divisions that privilege the masculine over the feminine and erase the lived body from the realm of politics. In each, a great deal of attention is paid to women's use and appropriations of dominant languages, symbolism and metaphor. ${ }^{2}$ Carol Stabile positions ecofeminists in contrast to cyborg enthusiasts. Critical of the valorization of the cyborg figure, Stabile argues, 'The promises of monsters and of the cyborg should not blind us to the cyborgs being forced upon us' (1994: 94). At the same time Stabile is also wary of ecofeminisms that often exhibit a 'puritanism' (12) by promoting a mythic sense of matriarchy and sisterhood (27-30). This, she argues, can lead to an essentialist view of women that fails to consider uses and engagements with technology that exist outside of normative notions of femininity and female embodiment. Similar to Stabile, Renate Klein is dubious of the cyborg's emancipatory potential. In her playfully titled essay, 'If I'm a cyborg rather than a goddess, will patriarchy go away?' Klein argues that the cyborg bears too much resemblance to technoscience discourses that medicalize and exploit women's bodies (1999: 197).

${ }^{3}$ Also wary of cyborg imaginaries, Judy Wajcman argues that we "need to beware of focusing on the cyborg image as a utopian aspirational icon in the service of feminism" (2004: 95). Yet with this claim, Wajcman also acknowledges the many ways in which Haraway's cyborg has been interpreted beyond and sometimes in conflict with her intentions. Wajcman argues that while many feminists latch onto the cyborg's multiplicity and destabilization of fixed roles and identities, they can forget that "real women do live physical difference in the flesh" (96). Wajcman suggests that this misreading is not accidental, but the result of 'Haraway's emphasis on playfulness and pleasure, as well as engagement and commitment ... [which] is at once seductive an d perplexing' (100). For Wajcman, the cyborg as a political figure is too metaphorical. She seeks a more concretized outline for not only imagining but enacting emancipatory techno-feminist subjectivity.

${ }^{4}$ While Greenham was the largest of the UK's anti-nuclear protest camps, it formed part of a much larger antinuclear and anti-war movement. The Campaign for Nuclear Disarmament had local branches throughout the UK. The relationship between feminis $\mathrm{m}$ and anti-militaris $\mathrm{m}$ was already being actively negotiated in women's liberation circles.

${ }^{5}$ The potency of the perimeter fence as both a symbol and a site was constructed in part through the circulation of media metaphors and images. Newspaper headlines constructed the fence as a marker of the place at which political action occurred. For example, British national newspapers ran headlines including, 'Greenham - where you can't sit on the fence,' 'Fury at the Fence,' and 'Cruise protesters attack fence.' 'W ire' became synonymous with the fence, as the two terms were used interchangeably to fix the location of protest. Headlines included, 'Women of Greenham' - 'women at the wire,' 'Greenham: Countdown at the wire,' and 'Linked hands circle wire at Greenham.'

${ }^{6}$ Spiders were another frequently reoccurring symbol in Greenham women's cultural imaginary. Buffie Johnson explains that the word spider, which comes from the Old English spinan meaning 'to spin', has signified a variety of different things across cultural and geographic contexts. Historically, the spider has been viewed as a goddess of fate, who 'weaves her home from her own body and spins the thread of life' (1988: 210). Almost exclusively imagined as a female, the spider is viewed as a protector, embodying both patience and industry (210). In the Odyssey the spider is a trickster figure, whereas the mythic Hopi Spider Woman is seen as the creator. In Jungian symbolism, the spider is a symbol of the self, representing parts of the personality that include the conscious and unconscious (213). Each of these meanings, and others, emerge at the 'foreground' of spider and web figures as they appeared at Greenham.

${ }^{7}$ Sarah's writing strongly resonates with anarchist and anarchafeminist work on technology. Both implicitly and explicitly some campers at Greenham combined anarchist critiques of technology with feminist critiques of patriarchy. Peggy Kornegger work has outlined this connection, arguing that 'Men can no longer be allowed to wantonly manipulate the environment for their own self-interest ... the presence of hierarchy and authoritarian 
mindset threaten our human and our planetary existence' (25). Here Kornegger cites Murray Bookchin's Towards A Liberatory Technology. Bookchin connects concerns for ecology with technological development in order to outline some possibilities for liberatory uses of technology. These liberatory uses would engage machines to limit the amount of toil required by work, freeing laborers to be craftsmen. Technology would be "based on....and tailored to the community" rather than driven by the accumulation of capital. (2004 [1965], 80-81). This attention to craft and vision of more just technological practices underlined much of Greenham women's daily life.

${ }^{8} \mathrm{http} / / /$ www.forbes.com/sites/briansolomon/2014/03/04/facebook-follows-a mazon-google-into-drones-with-60million-purchase/ 